\title{
Nitrogen balance studies with the milk-fed lamb
}

\author{
5.* Effect of frequency of feeding
}

\author{
By D. M. WALKER, L. J. COOK AND K. T. JAGUSCH \\ Department of Animal Husbandry, University of Sydney, Australia
}

(Received I 8 April 1966-Accepted I November 1966)

\footnotetext{
I. Thirty-three cross-bred lambs were given reconstituted dried whole cow's milk from I week of age at different levels of intake and at different frequencies of feeding.

2. Feeding frequency had no effect on live-weight gain, $\mathbf{N}$ retention or total body composition.

3. Lambs given two feeds daily had significantly heavier abomasums than pair-fed lambs given six feeds daily.

4. The weights of fat, protein $(\mathrm{N} \times 6.25)$ and water in the body were closely related to empty body weight; body composition (\% of empty body) was not significantly affected by the level of milk intake or by the rate of growth.

5. Live-weight gain was closely related to energy intake $(r=+0.99)$ and to $N$ retention $(r=+0.97)$. A live-weight gain of $100 \mathrm{~g}$ was associated with an intake of $5^{\mathrm{I}} \mathrm{I}$ kcal and a $\mathrm{N}$ retention of $2 \cdot 28 \mathrm{~g} \mathrm{~N}$.
}

Lambs and calves when reared with their dams are known to suckle at more frequent intervals than is usually practicable when they are hand-reared (Munro, 1955; Walker, 1950). There is at present no evidence that feeding frequency has any marked effect on the growth rate or utilization of energy and nitrogen by the preruminant lamb or calf (Voelker \& Jacobson, 1953), though studies with other animals suggest that both protein and fat metabolism may be affected (Cohn, 1962; Mochrie, 1964).

The present paper describes three experiments, with milk-fed lambs, in which the effect of frequency of feeding over a wide range of energy and $\mathrm{N}$ intakes was studied. In the first experiment, lambs were bottle-fed two, three or six times daily, the intakes of energy being similar but controlled throughout. In the second experiment, lambs which were allowed to feed $a d$ lib. twice daily were compared with pair-fed lambs given the same amount of milk in six feeds. In the third experiment, lambs were allowed to self-feed to appetite. The effect of feeding frequency on live-weight gain, $\mathrm{N}$ balance and total body composition was measured.

\section{EXPERIMENTAL}

\section{Experimental design}

Expt I. Comparison of two, three and six feeds daily. Fifteen male lambs were allotted at random to the dietary treatments. The experimental period of 4 weeks was divided into two equal periods (periods $I$ and 2). The diet was given for a preliminary period of $I$ week followed by a collection period of $I$ week. The intake of feed was determined by the live weight of the lamb at the beginning of each preliminary period, and was

* Paper no. 4: Br. F. Nutr. (1967), 21, 237. 
$12 \mathrm{r} \mathrm{kcal} / \mathrm{kg} 24 \mathrm{~h}$. Five lambs were allotted to each dietary treatment and each lamb was given the same dietary treatment in both experimental periods. The effects of the dietary treatments were estimated by multiple covariance analyses of the liveweight gain and nitrogen balance on mean live weight and calorie intake in periods 1 and 2.

Expt 2. Comparison of two and six feeds daily. Twelve lambs were used (ten male and two female). Two lambs of similar initial live weight and sex were paired and allotted at random to the dietary treatments. The lamb which was fed twice daily was allowed to drink to appetite at each feed. The total calorie intake of this lamb in $24 \mathrm{~h}$ was expressed as a proportion of the live weight $(\mathrm{kcal} / \mathrm{kg})$ and the paired lamb was fed at the same level of total intake in the subsequent six feeds. The diet was given for a preliminary period of 2 weeks followed by a collection period of $\mathrm{I}$ week. The effects of the dietary treatments were estimated by a paired $t$ test (Snedecor, 1956).

Expt 3. The intake of the lamb fed ad lib. Six lambs (five male and one female) were used. The diet was given ad lib. for a preliminary period of 2 weeks followed by a collection period of $\mathrm{I}$ week. The lambs in all the experiments were weighed daily at II.0O h, and live-weight gain was estimated by a regression analysis of the daily weights. Each regression equation is given in the text with the number of animals $(n)$, the correlation coefficient $(r)$, the residual standard deviation (RSD), and the RSD as a percentage of the mean of the dependent variable.

\section{Animals and their management}

Cross-bred lambs ((Border Leicester $\delta^{\star} \times$ Merino +$) \times$ Dorset Horn $\left.\delta^{\star}\right)$ were used. The lambs were born at pasture and, when the experiments began at between 3 and 7 days of age, their live weights ranged from $4 \cdot 3$ to $8.6 \mathrm{~kg}$. The experimental management, collection and storage of urine and faeces from male lambs in Expts $\mathrm{I}$ and 2 were as described for a previous experiment (Walker \& Faichney, 1964a). Faeces and urine from female lambs were collected together and homogenized before sampling. In Expt 3 lambs were fed on milk ad lib. from a reservoir surrounded by ice in an insulated box. The temperature of the milk was about $5^{\circ}$. After the first few days the lambs became accustomed to the cold milk and drank in excess of $100 \mathrm{ml}$ at frequent intervals. The quietness of the lambs and the long periods during which they rested, when compared with lambs given milk twice daily, suggested that the intake of milk was not limited by its temperature. A teat was fixed in position in the top of the metabolism cage and was connected by a Polythene tube to the reservoir (Pl. r). When the lamb ceased sucking, the milk in the tube flowed back into the reservoir.

The milk intake corresponding to the collection period of 7 days was calculated from one day before the beginning of the collection period (Expts 2 and 3 only).

The mean daily maximum and minimum temperatures in the animal house were as follows: Expt $\mathrm{r}$, maximum $29^{\circ}$, minimum $\mathrm{r} 7^{\circ}$; Expts 2 and 3 , maximum $24^{\circ}$, minimum $12^{\circ}$. 


\section{Diet}

The experimental diet used in all the experiments contained spray-dried whole cow's milk prepared commercially. This diet was similar in composition to that of diet no. 3 in the experiment of Walker \& Faichney $(1964 d)$. All the lambs were dosed with I ml of a groundnut-oil solution of 100000 i.u. vitamin A acetate and I0000 i.u. ergocalciferol during the Ist week of the experiment. Aureomycin soluble $(0.45 \mathrm{~g}$; Cyanamid of Great Britain Ltd), which contained chlortetracycline hydrochloride $(25 \mathrm{mg})$, was given daily, dissolved in the milk, to each lamb. A solution which contained $\mathrm{FeSO}_{4}, \mathrm{CuSO}_{4}$ and $\mathrm{CoCl}_{2}$ was added to all diets to increase the concentration of these metals in the dry matter by $50 \mathrm{ppm} \mathrm{Fe}, 5 \mathrm{ppm} \mathrm{Cu}$ and $0.1 \mathrm{ppm}$ Co.

The lambs in Expts $I$ and 2 were bottle-fed after the diets had been warmed to about $37^{\circ}$ by immersion in a constant-temperature bath. Feeding in Expt I was at 06.00 and $22.00 \mathrm{~h}, 06.00, \mathrm{I} 4.00$ and $22.00 \mathrm{~h}$, and $02.00,06.00,10.00, \mathrm{I} 4.00, \mathrm{I} 8.00$ and 22.00 h, for the two, three and six feed treatments, respectively. Feeding in Expt 2 was at the same times as in Expt I for the two and six feed treatments. In Expt 3 the level of milk in the reservoir was maintained by additions during the day so that a surplus was always available. Milk refused was weighed once daily.

\section{Analytical methods}

Dietary constituents, faeces and urine. Total $\mathrm{N}$, fat, ash, dry matter, urea and energy contents were determined by the methods used by Walker \& Faichney $(1964 a, b)$.

Body composition. The total body, after removal of gut contents and weighing of the abomasum and liver, was frozen, sectioned, minced finely, sampled and analysed for moisture, protein, fat and ash by the methods given by Walker \& Cook (1967).

Table I. Expt I. Nitrogen metabolism and live-weight gain of lambs given two, three or six feeds daily (mean values with their standard errors)

\begin{tabular}{|c|c|c|c|}
\hline & Two feeds & Three feeds & Six feeds \\
\hline $\begin{array}{l}\text { No. of lambs } \\
\text { Live weight }(\mathrm{kg})\end{array}$ & $\begin{array}{c}5 \\
8.53+0.41\end{array}$ & $\begin{array}{c}5 \\
0.14+0.71\end{array}$ & $\begin{array}{c}5 \\
8 \cdot 18+0.65\end{array}$ \\
\hline Energy intake (kcal/kg per week) & 700 & 705 & 702 \\
\hline$N$ intake ( $\mathrm{g} / \mathrm{kg}$ per week) & 5775 & $5 \cdot 78$ & $5 \cdot 75$ \\
\hline Urinary $\mathrm{N}$ excretion $(\mathrm{g} / \mathrm{kg}$ per week) & $2 \cdot 23$ & $2 \cdot 25$ & $2 \cdot 28$ \\
\hline Faecal $\mathrm{N}$ excretion ( $\mathrm{g} / \mathrm{kg}$ per week) & 0.18 & 0.20 & 0.20 \\
\hline $\mathrm{N}$ balance ( $\mathrm{g} / \mathrm{kg}$ per week) & $3 \cdot 34 \pm 0 \cdot 10$ & $3.33 \pm 0.03$ & $3.27 \pm 0.04$ \\
\hline Apparently digested $\mathrm{N}$ retained $(\%)$ : & $60 \cdot 1 \pm 1 \cdot 7$ & $60.1 \pm 0.7$ & $58 \cdot 9 \pm 1 \cdot 2$ \\
\hline Urea $N(\%$ of total urinary $N)$ & $72 \cdot 3 \pm 2 \cdot 7$ & $75 \cdot 2 \pm 2 \cdot 0$ & $72 \cdot 4 \pm 2 \cdot 3$ \\
\hline Live-weight gain ( $\mathrm{g} / \mathrm{kg}$ per week) & $95 \pm 2$ & $96 \pm 2$ & $93 \pm 2$ \\
\hline \multicolumn{4}{|l|}{ Apparent digestibility coefficient (\%): } \\
\hline $\begin{array}{l}\text { Dry matter } \\
\text { Total N }\end{array}$ & $\begin{array}{l}97.9 \pm 0.5 \\
96.9 \pm 0.6\end{array}$ & $\begin{array}{l}98 \cdot 0 \pm 0.2 \\
96 \cdot 5 \pm 0.6\end{array}$ & $\begin{array}{l}98.2 \pm 0.2 \\
96.6 \pm 0.5\end{array}$ \\
\hline
\end{tabular}

\section{RESULTS}

Expt $\mathrm{r}$. Mean values, with their standard errors, for the combined results in periods $\mathrm{I}$ and 2 are given in Table $\mathrm{I}$. There was no significant effect of dietary treatment on live-weight gain or $\mathrm{N}$ balance. The digested $\mathrm{N}$ retained (\%), urea $\mathrm{N}$ excretion and 
digestibility coefficients for dry matter and total $\mathrm{N}$ were also unaffected by treatment.

Table 2 gives the mean live-weight gain of the lambs in periods I and 2 . It was intended that all lambs, regardless of weight, should have the same intake of energy when expressed on a comparable basis in each period. However, although the energy intakes were the same when related to live weight $(\mathrm{kcal} / \mathrm{kg} 24 \mathrm{~h})$, the rate of gain

Table 2. Expt I. Intake of energy and live-weight gain per $24 h$ related to the mean live weight of the fifteen lambs in periods I and 2

\begin{tabular}{|c|c|c|c|}
\hline & Period $\mathrm{r}$ & Period 2 & $\begin{array}{l}\text { Significance of } \\
\text { differences }\end{array}$ \\
\hline Mean live weight $(\mathrm{kg})$ & $7 \cdot 65$ & $9 \cdot 5^{8}$ & $* * *$ \\
\hline Mean live weight $\left(\mathrm{kg}^{0.73}\right)$ & $4.4 \mathrm{I}$ & 5.19 & $* * *$ \\
\hline Live-weight gain: $\mathrm{g}$ & $95 \cdot 6$ & I39.9 & *** \\
\hline $\mathrm{g} / \mathrm{kg}$ & 12.5 & 14.6 & *** \\
\hline $\mathrm{g} / \mathrm{kg}^{0.73}$ & $21 \cdot 7$ & $26 \cdot 8$ & $* * *$ \\
\hline Energy intake: kcal & $770 \cdot 0$ & $960 \cdot 1$ & $* * *$ \\
\hline $\mathrm{kcal} / \mathrm{kg}$ & $100 \cdot 6$ & 100.2 & NS \\
\hline $\mathrm{kcal} / \mathrm{kg}^{0.73}$ & $173 \cdot 9$ & $184 \circ 0$ & $* * *$ \\
\hline $\begin{aligned} \text { Live-weight gain: } \mathrm{g} / \text { Mcal kg } \\
\mathrm{g} / \text { Mcal } \mathrm{kg}^{0.73}\end{aligned}$ & $\begin{array}{l}16 \cdot 0 \\
28 \cdot 0\end{array}$ & $\begin{array}{l}15 \cdot 0 \\
28 \cdot 0\end{array}$ & $\begin{array}{l}\text { NS } \\
\text { NS }\end{array}$ \\
\hline $\mathrm{g} / \mathrm{Mcal}$ & $124 \cdot 0$ & $145 \cdot 0$ & *** \\
\hline
\end{tabular}

Table 3. Expt 2. Nitrogen metabolism, live-weight gain, apparent digestibility of dry matter and $N$ and weights of liver and abomasum of lambs given two feeds ad lib. or pairfed six times daily (mean values)

No. of lambs

Live weight $(\mathrm{kg})$

Energy intake (kcal/kg per week)

$\mathrm{N}$ intake (g/kg per week)

Urinary $\mathrm{N}$ excretion $(\mathrm{g} / \mathrm{kg}$ per week $) \dagger$

Faecal N excretion ( $\mathrm{g} / \mathrm{kg}$ per week $) \dagger$

$\mathrm{N}$ balance (g/kg per week)

Apparently digested $\mathrm{N}$ retained (\%)

Urea $\mathrm{N}(\%$ of total urinary $\mathrm{N}) \ddagger$

Live-weight gain ( $\mathrm{g} / \mathrm{kg}$ per week)

Apparent digestibility coefficient (\%): Dry matterf Total Nł

Abomasum weight ( $\%$ of empty body weight)

Liver weight ( $\%$ of empty body weight)

\begin{tabular}{|c|c|}
\hline Two feeds & Six feeds \\
\hline 6 & 6 \\
\hline $\mathrm{I} I \cdot 8 \mathrm{I}$ & I I 33 \\
\hline I I I 2 & I II 3 \\
\hline סובי & 9.13 \\
\hline $3 \cdot 35$ & $3 \cdot 56$ \\
\hline 0.44 & 0.42 \\
\hline $\begin{array}{l}5 \cdot 31 \\
62 \cdot 5 \\
83 \cdot 9\end{array}$ & $\begin{array}{l}5 \cdot I 5 \\
58 \cdot I \\
84 \cdot I\end{array}$ \\
\hline 202 & I9I \\
\hline $97 \cdot 4$ & $97 \cdot 2$ \\
\hline $95 \% 4$ & $94 \cdot 8$ \\
\hline 0.55 & 0.39 \\
\hline 2.09 & $2 \cdot 32$ \\
\hline
\end{tabular}

Difference and standard error

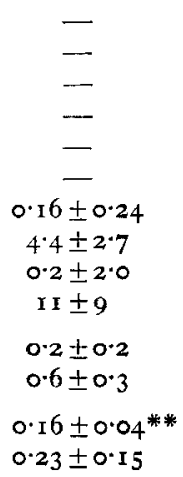

** $P<0.01$.

$\dagger$ Urinary $\mathrm{N}$ excretion of female lambs estimated from regression (for all other lambs) of urinary $\mathrm{N}$ on $\mathrm{N}$ intake. Faecal $\mathrm{N}$ by difference.

$\ddagger$ Mean of five values.

(g/kg $24 \mathrm{~h}$ ) was greater in period 2 than in period I. It is apparent that the energy intakes were, in fact, not the same when compared per unit of metabolic body size $\left(\mathrm{kg}^{0.73}\right)$, and that the lambs were being fed at a higher level of intake in period 2 than 
in period I. After allowance was made for this difference in energy intake the liveweight gain per $\mathrm{kg}$, or per $\mathrm{kg}^{0.73}$, was the same in each period.

Expt 2. Mean values for the results of this experiment are given in Table 3. There were no significant treatment effects on any of the measurements, except for the effect on the weights of the abomasum. The abomasum weights of lambs fed twice daily were significantly heavier $(P<0.0 \mathrm{I})$ than those of lambs fed six times daily.

Expt 3. Mean values, with their standard errors, for the results of this experiment are given in Table 4. One male lamb developed the habit of chewing and destroying the teat of the self-feed apparatus during the final week of the experiment, and was then unable to draw milk from the reservoir. His milk intake was consequently extremely variable during the collection period and his results were omitted from the mean.

Table 4. Expt 3. Nitrogen metabolism, live-zveight gain and apparent digestibility of dry matter and $N$ of lambs self-fed ad lib. (mean values with their standard errors)

\begin{tabular}{|c|c|}
\hline No. of lambs & 5 \\
\hline Live weight $(\mathrm{kg})$ & $12.14 \pm 0.70$ \\
\hline Energy intake: $\mathrm{kcal} / \mathrm{kg}$ per week & $1425 \pm 64$ \\
\hline Range & $1276-1585$ \\
\hline $\mathrm{N}$ intake (g/kg per week) & II. $68 \pm 0.52$ \\
\hline Urinary $N$ excretion $(\mathrm{g} / \mathrm{kg}$ per week)* & $4 \cdot 39$ \\
\hline Faecal $N$ excretion $(\mathrm{g} / \mathrm{kg} \text { per week })^{*}$ & 0.57 \\
\hline $\mathrm{N}$ balance $(\mathrm{g} / \mathrm{kg}$ per week) & $6.72 \pm 0.19$ \\
\hline Apparently digested $\mathrm{N}$ retained $(\%) \dagger$ & $60 \cdot 2 \pm I \cdot 9$ \\
\hline Urea $N(\%$ of total urinary $N) \uparrow$ & $74.7 \pm 4 \cdot 0$ \\
\hline Live-weight gain ( $\mathrm{g} / \mathrm{kg}$ per week) & $244 \pm 2 I$ \\
\hline \multicolumn{2}{|l|}{ Apparent digestibility coefficient $(\%)$ : } \\
\hline Dry matter $\uparrow$ & $97 \cdot 3 \pm 0 \cdot 4$ \\
\hline Total $\mathrm{N} \uparrow$ & $94.7 \pm 0.8$ \\
\hline
\end{tabular}

* Urinary $\mathrm{N}$ excretion for one female lamb estimated from regression (for all other lambs) of urinary $\mathrm{N}$ on $\mathrm{N}$ intake. Faecal $\mathrm{N}$ by difference.

+ Mean of four values.

\section{Body composition}

Mean values, with their standard errors, for the composition of the empty body ( $\%)$ are given in Table 5 and of the fat-free empty body in Table 6 . The effect of the dietary treatments in Expt 1 was estimated by covariance analysis of the weight of individual chemical components on empty body weight. The effect of dietary treatments in Expt 2 was estimated by a paired $t$ test on the percentage constituents of the empty body. There were no significant effects of different feeding frequencies on body composition in either Expt $\mathrm{I}$ or Expt 2.

The equations relating the weights of individual chemical components to empty body weight for lambs in all experiments $\left(n=3^{2}\right)$ were:

$$
\begin{aligned}
& \mathrm{W}=0.6 \mathrm{rgEBW}+0.70 \\
& \operatorname{RSD}= \pm 0.169(2.2 \%)(r=+0.99), \\
& \mathrm{P}=0.167 \mathrm{EBW}+0.20 \\
& \quad \mathrm{RSD}= \pm 0.088(4.3 \%)(r=+0.97), \\
& \mathrm{A}=0.03 \mathrm{IEBW}+0.07 \\
& \quad \mathrm{RSD}= \pm 0.048(\mathrm{I} \cdot 8 \%)(r=+0.82),
\end{aligned}
$$




$$
\begin{aligned}
\mathrm{F}= & 0.192 \mathrm{EBW}-\mathrm{I} \cdot 0 \mathrm{I} \\
& \operatorname{RSD}= \pm 0.169(15 \cdot \mathrm{I} \%)(r=+0.93),
\end{aligned}
$$

where $\mathrm{EBW}=$ empty body weight $(\mathrm{kg}), \mathrm{W}=$ water $(\mathrm{kg}), \mathrm{P}=$ protein $(\mathrm{N} \times 6.25)$ $(\mathrm{kg}), \mathrm{F}=$ fat $(\mathrm{kg})$ and $\mathrm{A}=$ ash $(\mathrm{kg})$ in the empty body weight.

The equations relating the weights of individual chemical components to fat-free

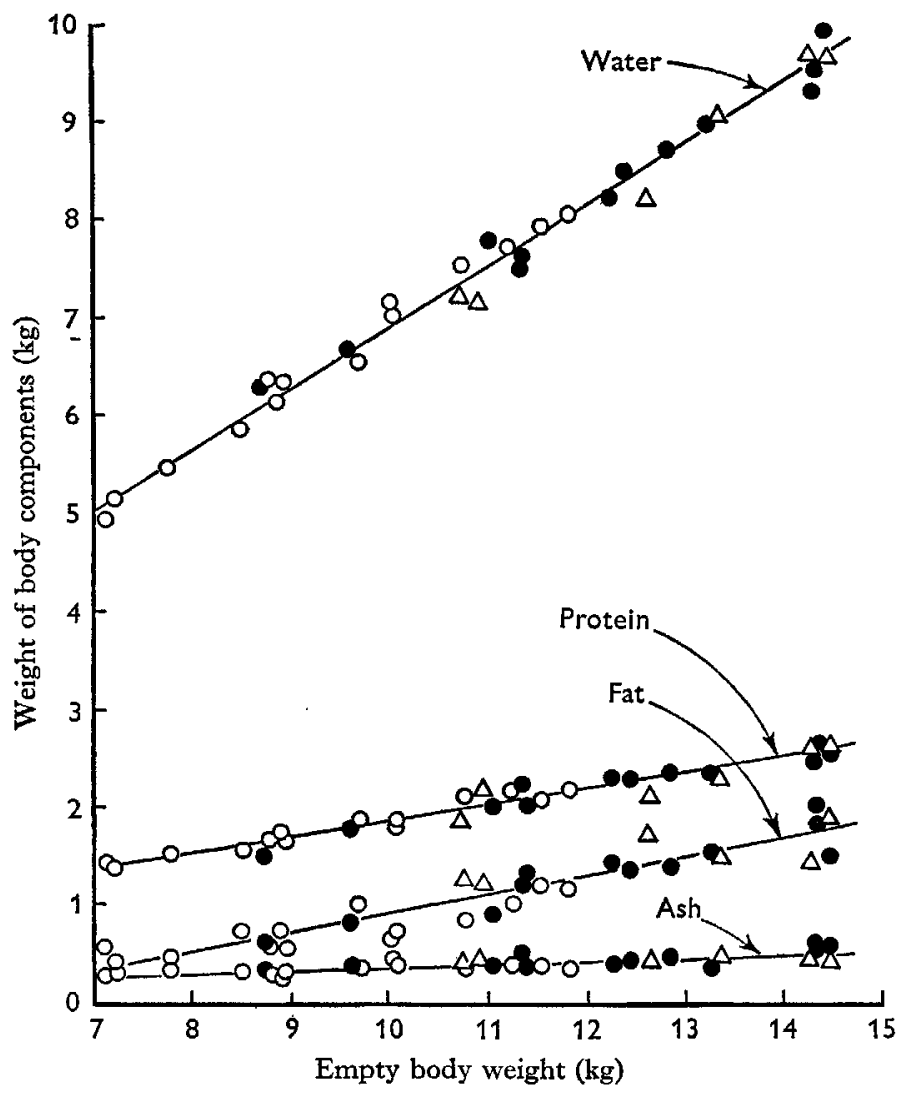

Fig. I. Relation between empty body weight of individual lambs and weight of body components. $O$, Expt I;, Expt 2; $\triangle$, Expt 3.

empty body weight $(n=32)$, were:

$$
\begin{aligned}
\mathrm{W}= & 0.766 \mathrm{FFE}-0.06 \\
& \mathrm{RSD}= \pm 0.086(\mathrm{I} \cdot \mathrm{I} \%)(r=+0.99), \\
\mathrm{P}= & 0.206 \mathrm{FFE} \\
& \mathrm{RSD}= \pm 0.087(4.3 \%)(r=+0.97), \\
\mathrm{A}= & 0.039 \mathrm{FFE}+0.02 \\
& \operatorname{RSD}= \pm 0.048(\mathrm{I} \cdot 8 \%)(r=+0.82), \\
\mathrm{F}= & 0.227 \mathrm{FFE}-\mathrm{I} \cdot \mathrm{I} 4 \\
& \operatorname{RSD}= \pm 0.066(5.9 \%)(r=+0.89),
\end{aligned}
$$


Vol. 21
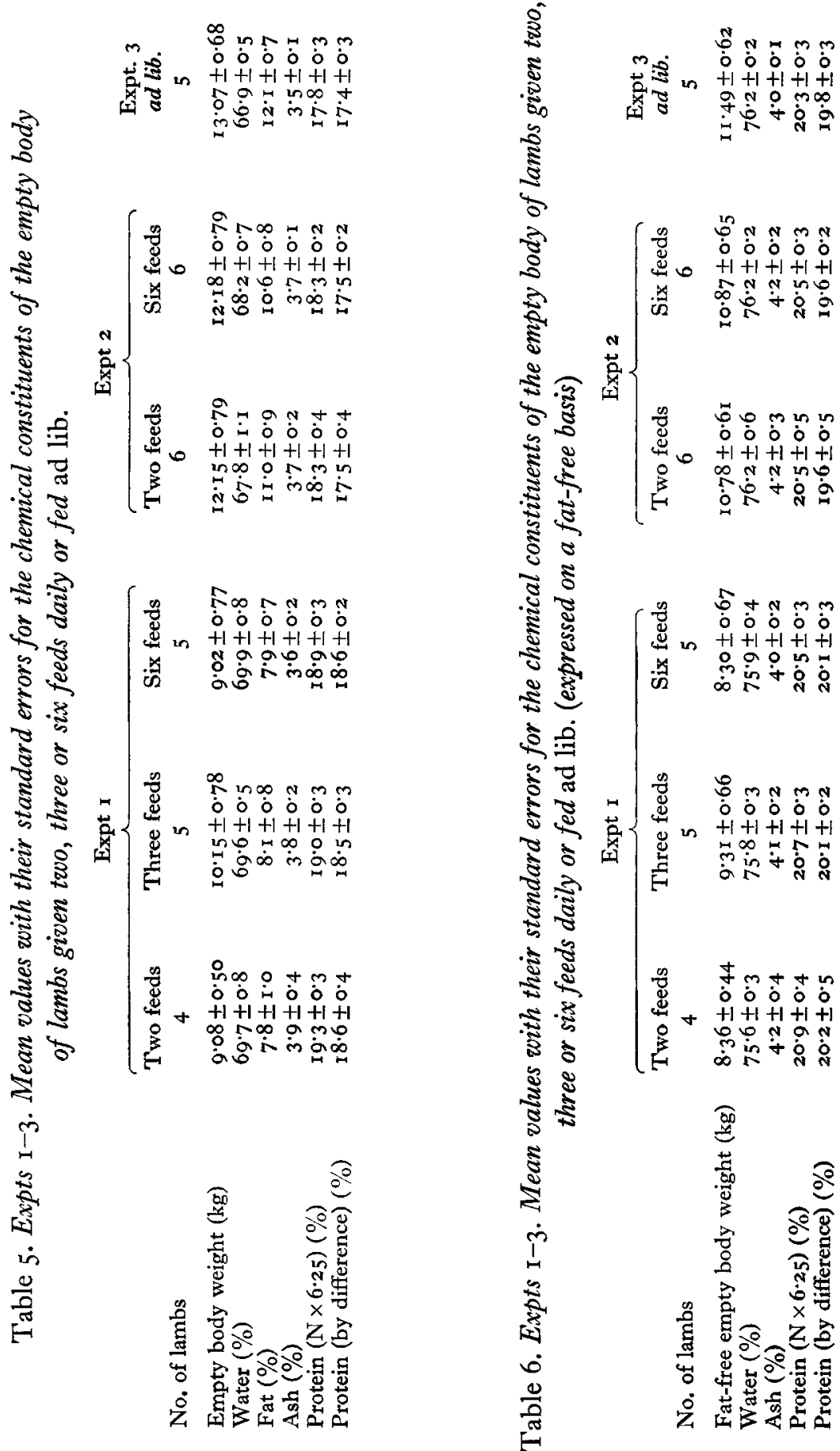
where $\mathrm{FFE}=$ fat-free empty body weight (kg), and W, P, A and F refer to the individual chemical components $(\mathrm{kg})$ in the fat-free empty body weight.

The relationships given in equations I $(a)$ to I $(d)$ and illustrated in Fig. I show that as the empty body weight increased so also did the contents of water, protein and fat. Although the lambs which were self-fed $a d$ lib. appeared to have a higher percentage of fat in the body than those given less total energy, an analysis of covariance of the weight of fat on empty body weight showed that these differences were not significant.

\section{DISCUSSION}

In our experiments there was no apparent effect of feeding frequency on the utilization by lambs of the energy or $\mathrm{N}$ in reconstituted dried whole cow's milk. It has been suggested that the utilization of dietary protein is affected by feeding frequency only when the intake of protein is high.

Krummacher (I896), Gebhardt (I897) and von Hoesslin \& Lesser (I9II) showed that if food was given throughout the day and not concentrated in one meal, there was a tendency for the amount of $\mathrm{N}$ excreted to decrease. Chanutin \& Mendel (I922) could not confirm these findings when they gave either low- or high-protein diets to dogs in single and fractional feedings. Mitchell (1923-4) was also unable to demonstrate any differences in the $\mathrm{N}$ utilization of low-protein diets given to rats in one, three or six feeds daily. At a higher protein level there was a tendency for the faecal $\mathrm{N}$ to be higher and for the urinary $\mathrm{N}$ to be lower in rats fed three times daily, than in rats given the same weight of food in one feed daily. Our examination of these results by analysis of variance showed that the differences in $\mathrm{N}$ retention were not significant.

Cohn and his associates (Cohn, Joseph, Bell \& Oler, r963; Cohn, Joseph, Bell $\&$ Frigerio, 1964) have reported that the excretion of urea is greater when rats are force-fed once or twice daily than when they are allowed to feed ad lib. Rakes, Lister \& Reid (1961) also observed that lambs aged 6 months had a $65 \%$ greater gain in weight and excreted $20 \%$ less $\mathrm{N}$ in the urine when fed eight times daily than pair-fed controls given one feed daily. Feeding frequency had no effect on the growth or $\mathrm{N}$ utilization of adult sheep.

The effect of protein level on the response to feeding frequency has been studied in experiments with man. Leverton \& Gram (1949) maintained the number of feeds constant but varied the frequency with which the protein component of the diet was fed. Young college girls were given $63 \mathrm{~g}$ protein daily as milk, which was taken with all three meals or only with lunch and dinner. The loss of $\mathrm{N}$ in the urine was greater when the protein was given at two meals than when distributed evenly between all three meals. Shortridge \& Linkswiler (1963) gave six young women $33 \mathrm{~g}$ protein daily and found that $\mathbf{N}$ retention was the same irrespective of whether the protein was given in three or six feeds daily. In their experiment egg protein was given as an integral part of the diet, and not as a separate component, as in the experiment of Leverton \& Gram (1949).

$\mathrm{Wu} \& \mathrm{Wu}\left(195^{\circ}\right)$ gave their subject, a man, an intake of $78 \mathrm{~g}$ protein for 4 days in two feeds and subsequently in four feeds daily. The protein intake was then gradually 
reduced to $5 \circ \mathrm{g}$ over a 2-week period and $\mathrm{N}$ retention was determined in successive 4-day periods, when meals were given two or four times daily. At the higher protein intake $\mathrm{N}$ excretion in the urine was slightly less and faecal $\mathrm{N}$ loss was slightly greater with four feeds daily than with two. The difference in $\mathrm{N}$ retention was barely significant. At the lower protein intake differences in feeding frequency did not affect $\mathrm{N}$ retention.

In our experiments, the $\mathrm{N}$ intake in Expt 2 was as high as could be obtained without force-feeding, yet no differences in $\mathrm{N}$ utilization were noted with the different intakes of energy and feeding frequency. The intakes of energy and $\mathrm{N}$ were higher in Expt 3 with ad lib. feeding, but no attempt was made to force-feed comparable amounts of milk to lambs in a limited number of feeds. The maximum intake of energy by a lamb in Expt 3 was $443 \mathrm{kcal} / \mathrm{kg}^{0.73} 24 \mathrm{~h}$. Kleiber (196r) presented values compiled from the literature, for animals ranging in size from chickens to steers, to show that the maximum intake of energy per unit of metabolic body size $\left(\mathrm{kg}^{0.75}\right)$ was about four to five times the basal heat production. Walker \& Faichney (1964a) reported that the basal heat production of lambs aged 5-8 weeks (i.e. lambs 2-5 weeks older than those used in the present experiments) was about $106 \mathrm{kcal} / \mathrm{kg}^{0.73} 24 \mathrm{~h}$. The intakes of energy in Expt 3 were thus about four times the basal heat production, and probably near the maximum for the diet given.

Apart from the effect of feeding frequency on $\mathrm{N}$ retention, many reports show that fat metabolism in several different species appears to be influenced by the frequency of feeding. Cohn and his associates (Cohn, Joseph \& Shrago, 1957; Cohn \& Joseph, 1959; Cohn, 1963) have reported consistently that their rats, when force-fed, have a greater content of fat in their bodies than rats eating the same quantity of feed ad lib. It would seem that this storage of fat is associated in some way with the force-feeding regime rather than with the frequency of feeding alone. Rats which were force-fed two, three or four times daily did not differ in their content of body fat, though the fat content was always high $(17 \cdot 5-19 \cdot 1 \%)$. In another experiment, rats self-fed ad lib. were compared with others trained to consume a similar quantity of food in $2 \mathrm{~h}$; here again there were no differences between the groups, but this time the content of body fat was lower $\left(9^{\circ} \cdot \mathrm{v} \cdot 10.4 \%\right)$. Feeding frequency appears to affect the body composition of chickens in an opposite way to that found by Cohn et al. (I957) with rats. Feigenbaum, Fisher \& Weiss (1962) equalized the feed intake of chickens selffed ad lib. ('nibblers') with those given two $\mathrm{I} h$ feeding periods daily ('meal eaters'). The 'nibblers' gained weight whilst the 'meal eaters' lost or merely maintained weight. The moisture content in the body was less in the 'nibblers' and the fat content was higher. The body protein contents of the two groups were the same.

Braude, Townsend, Harrington \& Rowell (1963) and Friend \& Cunningham (1964) were unable to find any effect of feeding frequency on the body composition of pigs.

In our experiments it was not expected that the body composition of the lambs would be affected by feeding frequency since there were no differences in growth rate or in the utilization of the dietary protein. The only difference observed was in the weights of the abomasum of lambs in Expt 2. Lambs which were fed twice daily had heavier abomasums than those fed six times daily. This result was not unexpected 
in view of the considerable volumes of milk taken at each feed. The mean weights of milk containing $15 \%$ total solids which were consumed in the different experiments were: $120^{\circ} 4 \mathrm{~g} / \mathrm{kg}$ mean live weight daily in Expt I, 188.0 in Expt 2 and $235^{\circ} 9$ in Expt 3 . Since the mean weight of the lambs varied from $7.6 \mathrm{~kg}$ in Expt I to $12.0 \mathrm{~kg}$ in Expt 3 the daily intake of milk varied from 924 to $2826 \mathrm{~g}$. Although the abomasum must have been stretched considerably, the distension disappeared within $2 \mathrm{~h}$ of feeding and there was no evidence of 'pot-bellies' in any of the lambs. This hypertrophy of the digestive organs has been observed in rats (Tepperman \& Tepperman, 1964) and in chickens (Feigenbaum et al. 1962 ) subjected to periodic overfeeding.

The milk intake per lamb was very high in both Expts 2 and 3, and it was expected that diarrhoea might result from the high intakes of sugar (cf. Walker \& Faichney, I $964 \mathrm{c}$ ). Mean values for the intakes of hexose equivalent and for the content of dry matter in the faeces are shown in Table 7. The equation relating these two variables, for all experiments with male lambs $(n=45)$, was:

$$
\begin{aligned}
& \mathrm{DM}=44.59-2.57 \mathrm{H} \\
& \quad \mathrm{RSD}= \pm 7.7(34 \cdot \mathrm{I} \%)(r=-0.63),
\end{aligned}
$$

where $\mathrm{H}=$ hexose equivalent intake $(\mathrm{g} / \mathrm{kg}$ live weight $24 \mathrm{~h})$ and $\mathrm{DM}=$ faecal drymatter content $(\%)$. If faeces containing less than $15 \%$ dry matter are classified as 'diarrhoeal' then the maximum intake of hexose equivalent, compatible with normal faeces, should be below I I $5 \mathrm{~g} / \mathrm{kg}$ live weight $24 \mathrm{~h}$. This value of $\mathrm{I}^{\circ} \cdot 5 \mathrm{~g}$ for reconstituted dried whole cow's milk is lower than the value of $\times 3.9 \mathrm{~g}$ derived from a previous study with ninety-nine lambs given a variety of semi-synthetic diets (Walker \& Faichney, 1964c).

Table 7. Expts $\mathrm{I}-3$. Intake of hexose equivalent by the lambs and

\begin{tabular}{|c|c|c|c|c|}
\hline & & Expt I & Expt 2 & Expt 3 \\
\hline Hexose equivalent intake ( $\mathrm{g} / \mathrm{kg} 24 \mathrm{~h}$ ) & $\begin{array}{l}\text { Mean } \\
\text { Range }\end{array}$ & $\begin{array}{c}6 \cdot 9 \\
6 \cdot 6-7 \cdot 1\end{array}$ & $\begin{array}{c}10.9 \\
10.0-11.6\end{array}$ & $\begin{array}{c}13.7 \\
\text { I } 16-15 \cdot 8\end{array}$ \\
\hline Faecal dry matter $(\%)$ & $\begin{array}{l}\text { Mean } \\
\text { Range }\end{array}$ & $\begin{array}{c}27 \cdot 6 \\
I 2 \cdot I-44 \cdot I\end{array}$ & $\begin{array}{c}\text { II.9 } \\
8 \cdot 9-I 5.9\end{array}$ & $\begin{array}{c}14.9 \\
\text { I0.3-23.9 }\end{array}$ \\
\hline
\end{tabular}
the dry-matter content of their faeces

Dried whole milk contains about half its total energy in the form of fat and about a quarter in the form of carbohydrate. Leveille \& Hanson (1966) have demonstrated that there was no effect of frequency of feeding on the activity of certain enzymes in rats when high-fat diets were given. In their diets over $70 \%$ of the total energy was derived from fat and no carbohydrate was present. It seems doubtful whether the composition of the diet used in the present experiment was solely responsible for the failure to show an effect of feeding frequency on $\mathbf{N}$ metabolism or total body composition.

When the results for Expts $1-3$ were combined, live-weight gain was closely related to energy intake. The equation for this relationship $(n=47)$ was:

$$
\begin{aligned}
& \mathrm{G}=0.196 \mathrm{E}-4^{8} \\
& \quad \operatorname{RSD}= \pm 20(10.0 \%)(r=+0.99),
\end{aligned}
$$

where $\mathrm{G}=$ live-weight gain $(\mathrm{g} / 24 \mathrm{~h})$, and $\mathrm{E}=$ energy intake $(\mathrm{kcal} / 24 \mathrm{~h})$. The range of energy intake was from 622 to $2728 \mathrm{kcal} / 24 \mathrm{~h}$ and live-weight gain from 6r to 
5I $5 \mathrm{~g} / 24 \mathrm{~h}$. In a previous experiment (Walker \& Faichney, I964d) the digestibility of the dry matter of dried whole cow's milk was shown to be closely related to energy digestibility $(n=24)$, the equation derived from the results of feeding diet no. 3 was:

$$
\begin{aligned}
& \mathrm{ED}=0.985 \mathrm{DMD}+2.3 \\
& \quad \mathrm{RSD}= \pm 0.5(0.5 \%)(r=+0.99)
\end{aligned}
$$

where $\mathrm{ED}=$ energy digestibility $(\%)$ and $\mathrm{DMD}=$ dry-matter digestibility $(\%)$. Since there was no effect of level of milk intake on dry-matter digestibility in the present experiment, live-weight gain was as closely related to the intake of digestible energy as to energy intake itself.

It has been shown frequently that the growth rate of lambs which are reared on the ewe is directly related to the intake of milk which they receive. Some correlation coefficients which have been obtained between milk intake and live-weight gain during the first 4 weeks of life include: 0.88-0.92 (Wallace, I948); 0.90 (Burris \& Baugus, I 955); 0.70 and 0.80 (Munro, I962). The maximum growth rate in these studies did not

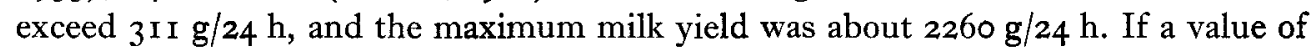
$\mathrm{I} 20 \mathrm{kcal} / \mathrm{IOO} \mathrm{g}$ is taken for the energy value of ewe's milk (Peirce, I934; Perrin, I958; Ling, Kon \& Porter, I96I) then the energy available would be about $2700 \mathrm{kcal} / 24 \mathrm{~h}$. This value is a maximum and clearly overestimates the energy intake of most lambs, since in our experiments the maximum intake of energy was also $2700 \mathrm{kcal} / 24 \mathrm{~h}$, associated with a live-weight gain of $515 \mathrm{~g} / 24 \mathrm{~h}$.

There was a very close relation between $\mathrm{N}$ balance and live-weight gain in our experiments. The regression equation $(n=47)$, was:

$$
\begin{aligned}
& \mathrm{NB}=0.0228 \mathrm{G}+\mathrm{I} \cdot 4^{\circ} \\
& \quad \mathrm{RSD}= \pm 0.7(\mathrm{II} \cdot 2 \%)(r=+0.97),
\end{aligned}
$$

where $\mathrm{NB}=\mathrm{N}$ balance $(\mathrm{gN} / 24 \mathrm{~h})$, and $\mathrm{G}=$ live-weight gain $(\mathrm{g} / 24 \mathrm{~h})$. The individual values are plotted in Fig. 2. It may be calculated from equations 4 and 6 that a gain of $100 \mathrm{~g}$ live weight was associated with an additional energy intake of $5^{\mathrm{II}} \mathrm{kcal}$ and a $\mathrm{N}$ retention of $2.28 \mathrm{~g} \mathrm{~N}$. The corresponding values in the experiment of Walker \& Faichney $(1964 d)$ for diet no. 3 were $610 \mathrm{kcal}$ and $2 \cdot 17 \mathrm{~g} \mathrm{~N}$. The regression equations from which these values were calculated ( $n=22$ and $n=24$ respectively) were:

$$
\begin{aligned}
& \mathrm{G}_{3}=0.1 \mathrm{I}_{4} \mathrm{E}_{3}-20 \\
& \mathrm{RSD}= \pm 2 \mathrm{I}(\mathrm{I} 5.4 \%)(r=+0.90), \\
& \mathrm{NB}_{3}=0.0217 \mathrm{G}_{3}+\mathrm{I} \cdot 10 \\
& \mathrm{RSD}= \pm 3.8(\mathrm{I} 3.7 \%)(r=+0.9 \mathrm{I}),
\end{aligned}
$$

where G, E and NB have the same meaning as in equations (4) and (6), and the subscript refers to diet no. 3 .

The results of Kern \& Wattenberg for young sheep, as cited by Armsby \& Moulton (1925), showed that $100 \mathrm{~g}$ live-weight gain had an energy content of $489 \mathrm{kcal}$ and contained $\mathrm{r} \cdot 8 \mathrm{I} \mathrm{g} \mathrm{N}$. Comparable values for milk-fed calves are reported by Blaxter \& Wood (195I), who found that a live-weight gain of $100 \mathrm{~g}$ was associated with an intake of $307 \mathrm{kcal}$ digestible energy and a N retention of $2.62 \mathrm{~g} \mathrm{~N}$. Brisson, Cunningham \& Haskell (1957) give values of $268 \mathrm{kcal}$ digestible energy and $3.22 \mathrm{~g} \mathrm{~N}$, and Roy, 
Gaston, Shillam, Thompson, Stobo \& Greatorex (1964) a value of $3^{\circ} 4^{\mathrm{I}} \mathrm{g} \mathrm{N}$ retained. These results agree with the findings of earlier workers, cited by Armsby \& Moulton (1925), that the protein content of the gain is higher, and the fat content lower, in calves than in lambs.

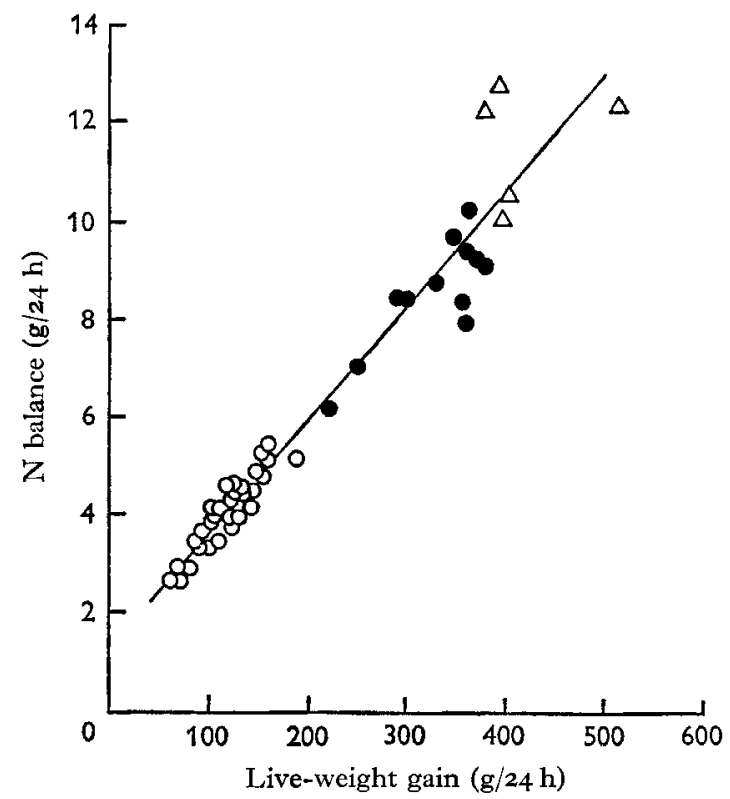

Fig. 2. Relation between live-weight gain of individual lambs and their gain of body nitrogen. $O$, Expt $1 ; 0$, Expt $2 ; \triangle$, Expt 3 .

$\mathrm{N}$ balance (range $2 \cdot 6-\mathrm{r} 2 \cdot 9 \mathrm{~g} \mathrm{~N} / 24 \mathrm{~h}$ ) was also closely related to $\mathrm{N}$ intake (range $4 \cdot 7-22 \cdot 4 \mathrm{~g} \mathrm{~N} / 24 \mathrm{~h}$ ) and to apparently digestible $\mathrm{N}$ intake. The regression equations ( $n=47$ and $n=44$ respectively) were:

$$
\begin{aligned}
& \mathrm{NB}=0.56 \mathrm{NI}+0.14 \\
& \operatorname{RSD}= \pm 0.5(8.4 \%)(r=+0.98), \\
& \mathrm{NB}=0.59 \mathrm{ADN}+0.05 \\
& \operatorname{RSD}= \pm 0.5(8.7 \%)(r=+0.98),
\end{aligned}
$$

where $\mathrm{NB}=\mathrm{N}$ balance $(\mathrm{g} \mathrm{N} / 24 \mathrm{~h}), \mathrm{NI}=\mathrm{N}$ intake $(\mathrm{g} \mathrm{N} / 24 \mathrm{~h})$, and $\mathrm{ADN}=$ apparently digestible $\mathrm{N}$ intake $(\mathrm{g} \mathrm{N} / 24 \mathrm{~h})$. The linear relation between $\mathrm{N}$ intake and $\mathrm{N}$ retention up to the highest levels of $\mathrm{N}$ intake emphasizes the intensity of $\mathrm{N}$ metabolism in the lamb, a capacity which has also been observed in calves (Blaxter \& Wood, 1951), and in our previous experiments with the lamb (Walker \& Faichney, 1964d).

The authors thank Mr B.W. Norton for his assistance in these experiments, Roche Products Pty. Ltd, Sydney, for a gift of vitamin A and ergocalciferol, and Cyanamid Australia Pty. Ltd for a gift of Aureomycin. 
British Fournal of Nutrition, Vol. 21, No. 2

Plate I

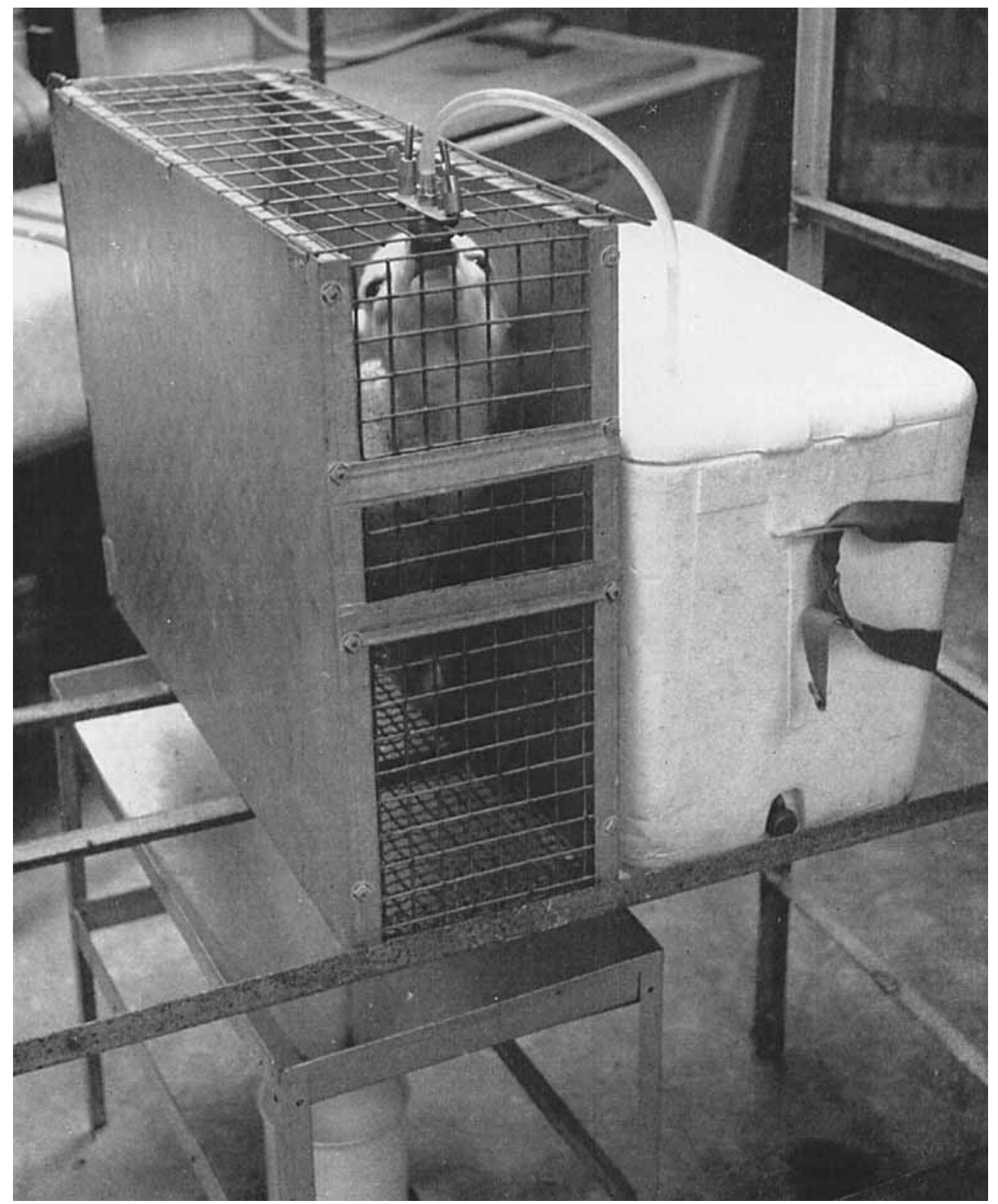

D. M. WALKER, L. J. COOK AND K. T. JAGUSCH

(Facing p. 287) 


\section{REFERENCES}

Armsby, H. P. \& Moulton, C. R. (1925). The Animal as a Converter of Matter and Energy. New York: The Chemical Catalog Company, Inc.

Blaxter, K. L. \& Wood, W. A. (1951). Br. F. Nutr. 5, 55.

Braude, R., Townsend, M. J., Harrington, G. \& Rowell, J. G. (1963). F. agric. Sci., Camb. 6o, 389.

Brisson, G. J., Cunningham, H. M. \& Haskell, S. R. (1957). Can. J. Anim. Sci. 37, 157.

Burris, M. J. \& Baugus, C. A. (1955). F. Anim. Sci. 14, I86.

Chanutin, A. \& Mendel, L. B. (1922). F. metab. Res. I, 48 I.

Cohn, C. (1962). Nutr. Rev. 20, 32 I.

Cohn, C. (1963). Ann. N.Y. Acad. Sci. 110, 395.

Cohn, C. \& Joseph, D. (1959). Am. F. Physiol. 196, 965.

Cohn, C., Joseph, D. \& Shrago, E. (1957). Metabolism 6, $38 \mathrm{I}$.

Cohn, C., Joseph, D., Bell, L. \& Frigerio, N. A. (1964). Proc. Soc. exp. Biol. Med. 115, 1057.

Cohn, C., Joseph, D., Bell, L. \& Oler, A. (1963). Am. F. Physiol. 205, 71.

Feigenbaum, A. S., Fisher, H. \& Weiss, H. S. (I962). Am. $¥$. clin. Nutr. 11, 312.

Friend, D. W. \& Cunningham, H. M. (1964). $\mathscr{~}$. Nutr. 83, 251.

Gebhardt, F. (1897). Arch. ges. Physiol. 65, 611.

von Hoesslin, H. \& Lesser, E. J. (I9I I). Hoppe-Seyler's Z. physiol. Chem. 73, 345.

Kleiber, M. (1961). The Fire of Life, p. 319. New York: John Wiley and Sons.

Krummacher, O. (1896). Z. Biol. 33, 108.

Leveille, G. A. \& Hanson, R. W. (I966). F. Lipid Res. 7, 46.

Leverton, R. M. \& Gram, M. R. (1949). F. Nutr. 39, 57.

Ling, E. R., Kon, S. K. \& Porter, J. W. G. (1961). In Milk: the Mammary Gland and Its Secretion. Vol. 2, p. 195. [S. K. Kon and A. T. Cowie, editors.] New York: Academic Press Inc.

Mitchell, H. H. (1923-4). F. biol. Chem. 58, 905.

Mochrie, R. D. (1964). Fedn Proc. Fedn Am. Socs exp. Biol. 23, 85.

Munro, J. (1955). Agric. Progr. 30, 129.

Munro, J. (1962). Anim. Prod. 4, 203.

Peirce, A. W. (1934). Aust. F. exp. Biol. Med. Sci. 12, 7.

Perrin, D. R. (1958). F. Dairy Res. 25, 215.

Rakes, A. H., Lister, E. E. \& Reid, J. T. (1961). F. Nutr. 85, 86.

Roy, J. H. B., Gaston, H. J., Shillam, K. W. G., Thompson, S. Y., Stobo, I. J. F. \& Greatorex, J. C. (1964). Br. F. Nutr. 18, 467.

Shortridge, L. J. \& Linkswiler, H. (1963). Fedn Proc. Fedn Am. Socs exp. Biol. 22, 320.

Snedecor, G. W. (1956). Statistical Methods, $5^{\text {th }}$ ed. Iowa: The Iowa State University Press.

Tepperman, H. M. \& Tepperman, J. (1964). Fedn Proc. Fedn Am. Socs exp. Biol. 23, 73.

Voelker, HI. \& Jacobson, N. L. (I953). F. Dairy Sci. 36, 592.

Walker, D. M. (1950). Bull. Anim. Behav. 8, 5 .

Walker, D. M. \& Cook, L. J. (I967). Br. F. Nutr. 2I, 237.

Walker, D. M. \& Faichney, G. J. (1964a). Br. F. Nutr. 18, 187.

Walker, D. M. \& Faichney, G. J. (1964b). Br. F. Nutr. 18, 201 .

Walker, D. M. \& Faichney, G. J. (1964c). Br. F. Nutr. 18, 209.

Walker, D. M. \& Faichney, G. J. (I964d). Br. F. Nutr. 18, 295.

Wallace, L. R. (1948). F. agric. Sci., Camb. 38, 93.

Wu, H. \& Wu, D. Y. (1950). Proc. Soc. exp. Biol. Med. 74, 78.

\section{EXPLANATION OF PLATE}

Lamb taking cold milk from self-feed apparatus. The milk reservoir inside the insulated container is connected by a Polythene tube to a teat inside the top of the metabolism cage. 